Situs Jurnal : $\underline{\text { http://ejurnal.stiepancasetia.ac.id/index.php/jieb }}$

Jilid 5 Nomor 1 Maret 2019

Hal $017-026$

\title{
ANALISIS SISTEM PENGENDALIAN INTERN PERSEDIAAN BAHAN BAKU PADA PT. FITRIA SARBINI MITRA MANDIRI KOTA BANJARBARU
}

\author{
Hendrayani*, Maria Anastasia, Endah Sri Bintari
}

Abstract: The purpose of this research is to find out the internal control system of raw material inventory at PT. Fitria Sarbini Mandiri Partners of Banjarbaru City during this time and To find out the internal control system of raw material inventory at PT. Fitria Sarbini The Independent Partner of Banjarbaru City that should be Descriptive research method and only uses a qualitative approach. The researcher only develops the concept and collects facts but does not conduct hypothesis testing and is carried out for 3 (three) months. Based on the results of research and analysis, the Internal Control System supplies raw materials of PT. Fitria Sarbini Mandiri Partners Banjarbaru City is already good, PT. Fitria Sarbini Mandiri Partner Banjarbaru City already has an itern control system procedure well, but in the future there are some things that must be considered like the finance department that performs transaction functions and records there should be an accounting section and can put professional and experienced employees in the company's job structure PT. Fitria Sarbini Mandiri Partners of Banjarbaru City.

Keywords: Raw Material, Inventory, Internal Control System

Abstrak: Tujuan dari penelitian ini adalah Untuk mengetahui sistem pengendalian intern persediaan bahan baku pada PT. Fitria Sarbini Mitra Mandiri Kota Banjarbaru selama ini dan Untuk mengetahui sistem pengendalian intern persediaan bahan baku pada PT. Fitria Sarbini Mitra Mandiri Kota Banjarbaru yang seharusnya. Metode penelitian deskriptif dan hanya menggunakan pendekatan kualitatif. Peneliti hanya mengembangkan konsep dan menghimpun fakta tetapi tidak melakukan pengujian hipotesis dan dilakukan selama 3 (tiga) bulan. Berdasarkan hasil penelitian dan analisis, Sistem Pengendalian Intern Persediaan bahan baku PT. Fitria Sarbini Mitra Mandiri Kota Banjarbaru sudah baik, PT. Fitria Sarbini Mitra Mandiri Kota Banjarbaru sudah memiliki prosedur sistem pengendalian intern dengan baik, namun kedepannya ada beberapa hal yang harus di perhatikan seperti pada bagian keuangan yang mengerjakan fungsi transaksi dan pencatatan seharusnya ada bagian akuntansi dan bisa menempatkan karyawan yang profesional dan berpengalaman pada stuktur jabatan perusahaan PT. Fitria Sarbini Mitra Mandiri Kota Banjarbaru.

Kata kunci : Sistem Pengendalian Intern, Persediaan, Bahan Baku

\section{Latar Belakang}

Sistem pengendalian bahan baku ini merupakan bagian yang sangat penting bagi perusahaan. Suatu sistem pengendalian intern dibutuhkan dalam setiap bagian perusahaan, agar tujuan perusahaan dapat tercapai secara efektif dan efisien. Hal ini dimaksudkan bahwa sistem pengendalian intern yang ada, tidak hanya dilakukan pada aspek-aspek yang memberi

\footnotetext{
* Lembaga Penjaminan Mutu Pendidikan (LPMP) Provinsi Kalimantan Selatan Jl.Gotong Royong No.85, Loktabat Utara, Banjarbaru Utara, Kota Banjarbaru, Kalimantan Selatan 
pemasukan saja, tetapi juga pada aspek-aspek yang memberikan beban pengeluaran bagi perusahaan.

Satu bagian yang menjadi sumber pengeluaran yang tidak dapat dihindari oleh perusahaan adalah dalam hal persediaan bahan baku. Disini penting bagi perusahaan untuk mengupayakan pemenuhan kebutuhan bahan baku yang cukup agar tidak terlalu besar dan tidak terlalu kecil dan terjamin kontinuitasnya, serta efektif dan efisien.

Sebuah sistem pengendalian juga tidak terlepas dari kenyataan bahwa suatu organisasi melibatkan individu-individu. Aktivitas individu ini diarahkan untuk mencapai tujuan organisasi. Karena ketidakselarasan tujuan dapat mengakibatkan tujuan organisasi atau tujuan individu tidak tercapai. Untuk itulah diperlukan suatu pengendalian kerja sehingga tujuan individu dapat selaras dengan tujuan organisasi. Salah satu alat untuk mencapai tujuan tersebut adalah adanya sistem pengendalian intern yang baik.

Dalam sistem pengendalian intern perlu di perhatikan unsur - unsur dalam sistem pengendalian intern tersebut adalah Struktur Organisasi yang Memisahkan Tanggung Jawab Fungsional secara Tegas, Sistem Wewenang dan Prosedur Pencatatan yang Memberikan Perlindungan yang cukup terhadap Kekayaan, Utang dan Biaya, Praktik yang Sehat dalam Melaksanakan Tugas dan Fungsi Setiap Unit Organisasi dan Karyawan yang Mutunya Sesuai dengan Tanggung Jawabnya.

Perusahaan akan menghadapi berbagai konsekuensi dalam mencapai tujuannya yang berkaitan dengan bahan baku, yaitu harus menanggung biaya maupun risiko yang berkaitan dengan persediaan. Terjadinya kekurangan persediaan bahan baku atau tidak adanya bahan baku pada saat dibutuhkan dapat menyebabkan jalannya aktivitas produksi terhenti, sebaliknya terlampau banyaknya persediaan bahan baku akan mengakibatkan tertahannya modal secara tidak produktif, sehingga hal ini merupakan salah satu faktor kerugian bagi perusahaan. PT. Fitria Sarbini Mitra mandiri Kota Banjarbaru merupakan perusahaan developer pengembang perumahan di Kota banjarbaru. PT. Fitria Sarbini Mitra Mandiri Kota Banjarbaru mengolah bahan baku berupa pasir, semen, kayu menjadi barang jadi berupa batako, kusen. Bahan baku yang dibutuhkan oleh PT. Fitria Sarbini Mitra Mandiri Kota Banjarbaru sebagian besar dibeli dari di daerah Kota Banjarbaru namun untuk pasir bisa memakai luar daerah yaitu pasir Barito Kuala. PT. Fitria Sarbini Mitra Mandiri Kota Banjarbaru memiliki persediaan bahan baku yang minimum digudangnya terutama semen dan keramik dan kusen, sehingga mereka tidak pernah mengalami kekurangan bahan baku. PT. Fitria Sarbini Mitra Mandiri Kota Banjarbaru tetap harus memperkirakan kapan mereka akan melakukan pembelian dengan baik dan harus pada jumlah yang tepat dan pada waktu yang tepat. PT. Fitria Sarbini Mitra Mandiri Kota Banjarbaru selama ini belum menggunakan sistem akuntansi pusat pertanggung jawaban yang terdapat dalam tiap divisi. Setiap divisi terdiri dari beberapa departemen dan tiap departemen terdiri dari beberapa seksi. Masing-masing manajer pada perusahaan ini memimpin satu seksi dan bertanggung jawab atas seksi yang dipimpinnya serta tiap manajer juga bertanggung jawab untuk mengendalikan biaya-biaya dan akan mempertanggung jawabkannya pada bagian penganggaran atau sering disebut dengan bagian perencanaan (planning) perusahaan. Karena bagian penganggaran sangat berperan penting dalam hal penyediaan bahan yang akan diproduksi oleh PT. Fitria Sarbini Mitra Mandiri Kota Banjarbaru dalam setiap tahunnya. Pentingnya pengendalian persediaan, mendorong penulis untuk mengetahui bagaimana penyediaan persediaan bahan baku yang dilakukan oleh PT. Fitria Sarbini Mitra Mandiri Kota Banjarbaru dalam kaitannya dengan sistem pengendalian intern, sehingga akan memberikan pemahaman lebih mengenai keunggulan dan kelemahan dari sistem tersebut. 


\section{Kajian Literatur}

Menurut Diana dan Setiawati (2013: 82) pengendalian internal adalah semua rencana organisasional, metode dan pengukuran yang dipilih oleh suatu kegiatan usaha untuk mengamankan harta kekayaanya, mengecek keakuratan dan keandalan data akuntansi usaha tersebut, meningkatkan efisiensi operasioanl dan mendukung dipatuhinya kebijakan manajerial yang telah ditetapkan. Pengendalian internal ini penting karena perusahaan suka tidak suka menghadapi banyak ancaman yang bisa mengganggu tercapainya tujuan sistem informasi akuntansi perusahaan.

Menurut Jones (2013: 132) pengendalian internal adalah suatu proses, yang dipengaruhi oleh dewan direksi, entitas, manajemen, dan personel lainya, yang dirancang untuk memberikan kepastian yang beralasan terkait dengan pencapaian sasaran kategori diantaranya adalah efektifitas dan efisiensi operasi, keandalan pelaporan keuangan dan ketaatan terhadap hukum dan peraturan yang berlaku. Sedangkan menurut Krismiaji (2015: 216) pengendalian intern adalah rencana organisasi dan metode yang digunakan untuk menjaga atau melindungi aktiva, menghasilkan informasi yang akurat dan dapat dipercaya, memperbaiki efisiensi dan untuk mendorong ditaatinya kebijakan manajemen.

Menurut Diana dan Setiawati (2013: 82) COSO mendefinisikan pengendalian internal sebagai proses yang diimplementasikan oleh dewan direksi, manajemen, serta seluruh staf dan karyawan dibawah arahan mereka dengan tujuan untuk memberikan jaminan yang memadai atas tercapainya tujuan pengendalian. Tujuan pengendalian tersebut meliputi, efektifitas dan efisiensi operasi, reliabilitas pelaporan keuangan dan juga kesesuaian dengan aturan dan regulasi yang ada. COSO adalah sebuah organisasi swasta yang beranggotakan the American accounting Association (AAA), AICPA, the Insitute of Internal Auditor (IIA), the Institute of Management Accountants (IMA) dan the Financial Executives Institute (FEI). Organisasi ini pada tahun 1992 mengeluarkan hasil sebuah studi untuk menghasilkan definisi pengendalian intern, yang dikenal dengan model pengendalian intern (Internal Control Model). Produk COSO ini segera diterima secara luas sebagai otoritas pengendalian intern oleh manajemen, akuntan, auditor dan para pemakai laporan keuagan (Krismiaji, 2015: 220).

Menurut Romney dan Steinbart $(2015: 227)$ pengendalian internal menjalankan tiga fungsi penting sebagai berikut:

1. Pengendalian Preventif adalah pengendalian yang mencegah masalah sebelum timbul. Contoh: merekrut personil berkualifikasi, memisahkan tugas pegawai dan mengendalikan akses fisik atas aset dan informasi.

2. Pengendalian Detektif adalah pengendalian yang menemukan masalah yang tidak terelakkan. Contoh: menduplikasi pengecekan kalkulasi dan menyiapkan rekonsiliasi bank serta neraca saldo bulanan.

3. Pengendalian Korektif adalah pengendalian yang mengidentifikasi dan memperbaiki masalah serta memperbaiki dan memulihkanya dari kesalahan yang dihasilkan. Contoh: pengumpulan ulang transaksi-transaksi untuk pemrosesan selanjutnya.

Menurut Krismiaji (2015: 213) tujuan dilakukanya pengendalian adalah untuk mencegah timbulnya kerugian bagi sebuah organisasi, yang timbul antara lain karena sebab-sebab sebagai berikut:

1. Penggunaan sumber daya yang tidak efisien dan boros

2. Keputusan manajemen yang tidak baik

3. Kesalahan yang tidak disengaja dalam pencatatan dan pemrosesan data

4. Kehilangan atau kerusakan catatan secara tidak sengaja

5. Kehilangan aktiva karena kecerobohan karyawan

6. Perubahan secara tidak sah terhadap SIA atau komponen-komponenya 
Menurut Mulyadi (2014: 164-170) unsur-unsur yang ada dalam sistem pengendalian intern adalah:

1. Struktur Organisasi yang Memisahkan Tanggung Jawab Fungsional secara Tegas. Di dalam perusahaan manufaktur harus dipisahkan fungsi-fungsi operasi dan penyimpanan dari fungsi akuntansi. Suatu fungsi tidak boleh diberi tanggung jawab penuh untuk melaksanakan semua tahap suatu transaksi. Dengan pemisahan fungsi akuntansi dari fungsi-fungsi operasi dan fungsi penyimpanan, catatan akuntansi yang diselenggarakan dapat mencerminkan transaksi sesungguhnya

2. Sistem Wewenang dan Prosedur Pencatatan yang Memberikan Perlindungan yang cukup terhadap Kekayaan, Utang dan Biaya. Dalam organisasi, setiap transaksi hanya terjadi atas dasar otorisasi dari pejabat yang memiliki wewenang untuk menyetujui terjadinya transaksi tersebut. Oleh karena itu, dalam organisasi harus dibuat sistem yang meengatur pembagian wewenang untuk otorisasi atas terlaksananya setiap transaksi.

3. Praktik yang Sehat dalam Melaksanakan Tugas dan Fungsi Setiap Unit Organisasi. Caracara yang ditmpuh perusahaan dalam menciptakann praktik yang sehat adalah;
a. Penggunaan formulir bernomor urut tercetak yang pemakaianya harus dipertanggungjawabkan oleh yang berwenang.
b. Pemeriksaan mendadak
c. Setiap transaksi tidak boleh dilaksanakan dari awal sampai akhir oleh satu orang atau satu organisasi.
d. Perputaran jabatan.
e. Keharusan pengambilan cuti bagi karyawan yang berhak.
f. Secara periodik diadakan pencocokan fisik kekayaan dengan catatanya,

4. Karyawan yang Mutunya Sesuai dengan Tanggung Jawabnya. Unsur mutu karyawan merupakan unsur sistem pengendalian intern yang paling penting. Jika perusahaan memiliki karyawan yang kompeten dan jujur, unsur pengendalian yang lain dapat dikurangi sampai batas yang minimum

Dalam proses industri konstruksi membutuhkan banyak persediaan bahan baku/material yang akan digunakan dalam sebuah proyek konstruksi, dengan tersedianya bahan baku maka diharapkan proses konstruksi sesuai dengan kebutuhan. Selain itu dengan adanya persediaan bahan baku yang tersedia diharapkan dapat memperlancar kegiatan/proses proyek konstruksi dan dapat menghindari terjadinya kekurangan bahan baku serta keterlambatan jadwal pengiriman persediaan bahan baku yang dapat merugikan perusahaan dalam hal ini image yang kurang baik. Agar lebih mengerti maksud dari persediaan, maka dapat dikemukakan beberapa pendapat mengenai pengertian dari persediaan, sebagai berikut:

1. Menurut Prawirosentono (2014:61), persediaan adalah aktiva lancar yang terdapat dalam perusahaan dalam bentuk persediaan bahan mentah (bahan baku/raw material, bahan setengah jadi/work in process dan barang jadi/finished goods).

2. Persediaan adalah bagian utama dari modal kerja, merupakan aktiva yang pada setiap saat mengalami perubahan (Gitosudarmo,2014:93).

3. Soemarsono (2014:246), mengemukakan pengertian persediaan sebagai barang-barang yang dimiliki perusahaan untuk dijual kembali atau digunakan dalam kegiatan perusahaan.

4. Inventory atau persediaan barang sebagai elemen utama dari modal kerja merupakan aktiva yang selalu dalam keadaan berputar, dimana secara terusmenerus mengalami perubahan. (Riyanto,2014:69). 
5. Sedangkan menurut PSAK No.14 Paragraf 3, menyatakan pengertian persediaan adalah aktiva:

a. Tersedia untuk dijual dalam usaha kegiatan normal.

b. Dalam proses produksi dan atau dalam perjalanan

c. Dalam bentuk bahan atau perlengkapan (supplies)

Timbulnya persediaan dalam suatu sistem, baik sistem manufaktur maupun non manufaktur adalah merupakan akibat dan kondisi-kondisi sebagai berikut (Arman dan Yudha, 2014) :

1. Mekanisme pemenuhan atas permintaan (transaction move). Permintaan akan suatu barang tidak akan dapat dipenuhi dengan segera apabila barang tersebut tidak tersedia sebelumnya, karena untuk mengadakan barang tersebut diperlukan waktu untuk pembuatannya maupun mendatangkannya. Hal ini berarti bahwa adanya persediaan merupakan hal yang sulit dihindarkan.

2. Adanya keinginan untuk meredam ketidakpastian (precautionary motive). Ketidakpastian yang dimaksud adalah:

a. Adanya permintaan yang bervariasi dan tidak pasti dalam jumlah maupun waktu kedatangan.

b. Waktu ancang-ancang (lead time) yang cenderung tidak pasti karena berbagai faktor yang tak dapat dikendalikan sepenuhnya

c. Ketidakpastian ini akan diredam oleh jenis persediaan yang disebut persediaan pengaman (safety stock).

Persediaan pengaman ini digunakan jika permintaan melebihi peramalan produksi lebih rendah dari rencana atau waktu ancang-ancang (lead time) lebih panjang dari yang diperkirakan semula. Adanya persedian menimbulkan konsekuensi resiko-resiko tertentu yang harus ditanggung perusahaan akibat persediaan tersebut. Persediaan yang disimpan perusahaan bisa saja rusak sebelum digunakan. Selain itu perusahaan juga harus menanggung biaya-biaya yang timbul akibat adanya persediaan tersebut. Adapun alasan perlunya persediaan adalah:

1. Transaction Motive, menjamin kelancaran proses pemenuhan (secara ekonomis) permintaan barang sesuai dengan kebutuhan pemakai. Operating Stock (qo) $=$ Persediaan operasi dapat berjalan paling baik EOQ.

2. Precatuionary Motive, Meredam fluktuasi permintaan/pasokan yang tidak beraturan. Fluktuasi $=$ rata-rata demand + Safety Stock Ditentukan (cari yang paling kritis).

3. Speculation Motive, alat spekulasi untuk mendapatkan keuntungan berlipat dikemudian hari. Persediaan dapat bersifat speculator.

\section{Metode Penelitian}

Penelitian ini menggunakan metode penelitian deskriptif karena dalam pelaksanaannya meliputi data, analisis dan interpretasi tentang arti dan data yang diperoleh. Penelitian ini disusun sebagai penelitian induktif yakni mencari dan mengumpulkan data yang ada di lapangan dengan tujuan untuk mengetahui faktor-faktor, unsur-unsur bentuk, dan suatu sifat dari fenomena di masyarakat. (Nazir, 2012: 51). berikut:

Pada Penelitian ini penulis menggunakan teknik pengumpulan data antara lain sebagai

1. Studi Kepustakaan (Library Research) 
Penelitian ini dimaksudkan untuk memperoleh landasan teori dengan mempelajari atau membaca dari berbagai literatur menurut beberapa para ahli yang berhubungan dengan masalah yang diteliti yang dapat menunjang penelitian tentang "Sistem Pengendalian Itern Terhadap Persediaan Bahan Baku.

2. Studi Lapangan (Field Riset)

Teknik pengumpulan data primer dengan cara mengadakan penelitian secara langsung terhadap abjek dan masalah-masalah yang berhubungan dengan objek penelitian yang bersangkutan dengan cara:

a. Observasi

Penulis mengadakan peninjauan secara langsung pada objek yang akan dibahas dan mengumpulkan semua data yang dibutuhkan serta dapat dipercaya kebenarannya dan permasalahannya harus sesuai dengan apa yang akan disusun oleh penulis.

b. Wawancara

Data yang dibutuhkan oleh penulis didapat dengan cara menanyakan secara langsung (wawancara) sesuai dengan topik yang akan dibahas oleh penulis

Data yang telah diperoleh dari laporan pencatatan persediaan bahan baku perusahaan kemudian dianalisis dengan analisis deskriptif, yaitu menguraikan dari beberapa teori yang berhubungan dengan Sistem Pengendalian Intern sebagai berikut:

1. Menggambarkan pembahasan tentang sistem pengendalian intern persediaan bahan baku pada PT. Fitria Sarbini Mitra Mandiri Kota Banjarbaru selama ini

2. Menggambarkan sistem pengendalian intern persediaan bahan baku pada PT. Fitria Sarbini Mitra Mandiri Kota Banjarbaru yang seharusnya

3. Kemudian akan di impilikasikan pada hasil penelitian dan ditarik kesimpulan dan saran saran yang diperlukan untuk memperbaiki dan mengatasi permasalahan yang terjadi

\section{Hasil Penelitian dan Pembahasan}

Pencatatan persediaan bahan baku pada PT. Fitria Sarbini Mitra Mandiri Kota Banjarbaru selama ini dalam mengelola bahan baku persediaan adalah sebagai berikut:

1. Order

Dalam order barang PT. Fitria Sarbini Mitra Mandiri Kota Banjarbaru tidak ada menyediakan formulir atau kartu order, order dilakukan hanya lewat telepon maupun pesan untuk di antar barang sesuai pesanan, pencatatan hanya dilakukan oleh karyawan yang ditunjuk menangani.

2. Barang Masuk

Barang masuk pada PT. Fitria Sarbini Mitra Mandiri Kota Banjarbaru juga tidak ada formulir atau kartu barang masuk, setelah barang datang langsung masuk gudang, pencatatan hanya dilakukan oleh karyawan yang ditunjuk menangani.

3. Barang Keluar

Barang keluar pada PT. Fitria Sarbini Mitra Mandiri Kota Banjarbaru dikendalikan dengan menggunakan kartu barang keluar gudang, hal ini dilakukan untuk mengontrol jumlah barang keluar yang di pakai tukang untuk membangun rumah, adapun kartu barang keluar pada PT. Fitria Sarbini Mitra Mandiri Kota Banjarbaru selama ini dapat dilihat pada tabel 1.

Tabel 1. Kartu Barang Keluar PT. Fitria Sarbini Mitra Mandiri Kota Banjarbaru

No. Hari/Tanggal Nama Barang Jumlah \begin{tabular}{llc} 
Blok/No & $\begin{array}{c}\text { Nama } \\
\text { Tukang }\end{array}$ & $\begin{array}{c}\text { Tanda } \\
\text { Tangan }\end{array}$ \\
\hline
\end{tabular}




\begin{tabular}{cccccc}
\hline 1. & $\begin{array}{c}\text { Jum'at / 06 } \\
\text { Juli 2018 }\end{array}$ & Semen & 10 Sak & D.2 & Junaidi \\
\hline 2. & $\begin{array}{c}\text { Sabtu / 07 Juli } \\
2018\end{array}$ & Besi 8 in & $\begin{array}{c}5 \\
\text { Batang }\end{array}$ & A.6 & Imran \\
\hline
\end{tabular}

4. Barang Kembali / Rusak / Return

Pengebalian barang yang rusak PT. Fitria Sarbini Mitra Mandiri Kota Banjarbaru belum ada disediakan formulir, kartu kendali atau surat pengembalian, selama ini perusahaan dengan toko pemasok bahan baku sudah saling percaya sehingga apabila ada barang yang rusak toko langsung menukar ganti dengan yang baru, kecuali barang - barang tertentu yang harus sesuai perjanjian terlebih dahulu dan pengecekan setelah serah terima barang, pencatatan hanya dilakukan oleh karyawan yang ditunjuk menangani.

Dalam proses pembuatan Rumah pada PT. Fitria Sarbini Mitra Mandiri Kota Banjarbaru prosesnya dapat di gambarkan pada alir gambar 1.

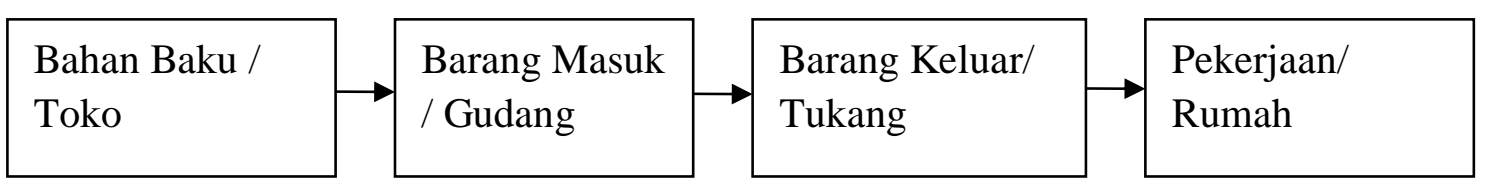

\section{Gambar 1. Diagram Alur RAB}

Analisis kualitatif dilakukan untuk menjawab identifikasi dengan cara mengumpulkan data perusahaan dan mewawancarai narasumber untuk mengetahui perkembangan data yang kita peroleh dan menghubungkan dengan teori. Berikut ini adalah penjelasan dari sistem dan prosedur pada PT. Fitria Sarbini Mitra Mandiri Kota Banjarbaru selama ini:

1. Prosedur Permintaan dan Pengeluaran Bahan Baku dari Gudang Pengeluaran bahan baku merupakan awal dimulainya suatu proses produksi. Setiap bahan baku yang dikeluarkan, terlebih dahulu harus disetujui atau atas perintah petugas yang berwenang. Bagian atau fungsi yang terkait, dokumen, catatan akuntansi, prosedur dan sistem dalam prosedur pengeluaran bahan baku dari gudang PT. Fitria Sarbini Mitra Mandiri Kota Banjarbaru adalah sebagai berikut:

a. Fungsi yang Terkait Fungsi yang terkait dalam permintaan dan pengeluaran bahan baku dari gudang pada PT. Fitria Sarbini Mitra Mandiri Kota Banjarbaru adalah:

1) Fungsi Produksi. Fungsi ini dilaksanakan bagian produksi yang bertanggung jawab atas pelaksanaan produksi.

2) Fungsi Gudang. Fungsi ini dilaksanakan oleh bagian gudang yang bertanggung jawab atas pelayanan permintaan bahan baku atas permintaan bagian produksi untuk kebutuhan proses produksi.

3) Fungsi Akuntansi Fungsi ini bertanggung jawab mencatat pemakaian bahan baku dalam kartu persediaan.

b. Catatan Akuntansi Catatan akuntansi yang digunakan untuk mencatat transaksi permintaan dan pengeluaran barang gudang di PT. Fitria Sarbini Mitra Mandiri Kota Banjarbaru adalah kartu Persediaan. Kartu ini berfungsi untuk mencatat mutasi setiap persediaan. 
c. Prosedur Permintaan dan Pengeluara Bahan Baku dari Gudang Prosedur permintaan dan pengeluaran bahan baku dari gudang pada PT. Fitria Sarbini Mitra Mandiri Kota Banjarbaru mencakup prosedur sebagai berikut:

1) Bagian produksi, meminta barang ke bagian gudang secara lisan saat bagian produksi membutuhkan barang untuk proses produksi.

2) Bagian gudang, tugasnya menyiapkan barang yang diminta oleh bagian produksi. menyerahkan barang yang diminta ke bagian produksi, mencatat barang yang diminta dalam kartu gudang.

3) Bagian Keuangan, tugas bagian kartu persediaan menerima laporan permintaan pemakaian bahan baku secara lisan dari fungsi gudang dan fungsi produksi, membuat jurnal pemakaian bahan baku. Bagian kartu persediaan kemudian mencatat pemakaian bahan baku pada kartu persediaan.

2. Prosedur Pengembalian Bahan Baku ke Gudang Fungsi yang terkait, catatan akuntansi dan sistem dalam prosedur pengembalian bahan baku ke gudang PT. Fitria Sarbini Mitra Mandiri Kota Banjarbaru adalah sebagai berikut:

a. Fungsi yang Terkait Fungsi yang terkait dalam pengembalian bahan baku dari gudang pada PT. Fitria Sarbini Mitra Mandiri Kota Banjarbaru adalah:

1) Fungsi Produksi. Fungsi ini dilaksanakan bagian produksi yang bertanggung jawab atas seluruh kegiatan produksi

2) Fungsi Gudang. Fungsi ini dilaksanakan oleh bagian gudang yang bertanggung jawab atas penerimaan bahan baku yang diberikan oleh fungsi produksi.

3) Fungsi Akuntansi Fungsi ini bertanggung jawab mencatat pengembalian bahan baku dalam kartu persediaan.

b. Catatan Akuntansi Catatan akuntansi yang digunakan untuk mencatat transaksi pengembalian bahan baku ke gudang di PT. Fitria Sarbini Mitra Mandiri Kota Banjarbaru adalah kartu persediaan, kartu ini berfungsi untuk mencatat mutasi setiap persediaan.

c. Prosedur Pengembalian Bahan Baku ke Gudang Prosedur pengembalian bahan baku ke gudang pada PT. Fitria Sarbini Mitra Mandiri Kota Banjarbaru mencakup prosedur sebagai berikut:

1) Bagian Produksi, tugasnya mengirimkan barang ke bagian gudang.

2) Bagian Gudang, tugasnya menerima barang dari bagian Gudang, menghitung jumlah barang yang dikembalikan, dan mengisi perubahan kuantitas barang pada kartu gudang

3) Bagian Keuangan, tugasnya menerima laporan secara lisan dari bagian gudang dan produksi tentang pengembalian bahan baku

d. Mengisi perubahan kuantitas barang pada kartu persediaan dan membuat jurnal umum

\section{Kesimpulan}

Dari hasil penelitian mengenai Analisis Sistem Pengendalian Intern Persediaan Bahan Baku Pada PT. Fitria Sarbini Mitra Mandiri Kota Banjarbaru kesimpulan sebagai berikut:

1. Sistem Pengendalian Intern Persediaan Bahan Baku selama ini pada PT. Fitria Sarbini Mitra Mandiri Kota Banjarbaru yaitu PT. Fitria Sarbini Mitra Mandiri Kota Banjarbaru adalah:

a. Struktur Organisasi yang Memisahkan Tanggung Jawab Fungsional secara Tegas.

Struktur organisasi PT. Fitria Sarbini Mitra Mandiri Kota Banjarbaru masih banyak diisi oleh orang - orang pendiri perusahaan. 
b. Sistem Wewenang dan Prosedur

PT. Fitria Sarbini Mitra Mandiri Kota Banjarbaru dalam pencatatan dan transaksi dilakukan oleh manager keuangan dan bawahannya atas persetujuan direktur perusahaan.

c. Praktik yang Sehat dalam Melaksanakan Tugas dan Fungsi Setiap Unit Organisasi.

PT. Fitria Sarbini Mitra Mandiri Kota Banjarbaru dalam Praktik yang Sehat dalam Melaksanakan Tugas dan Fungsi Setiap Unit Organisasi telah membuat alur standar persediaan bahan baku dan pengembalian bahan baku.

d. Karyawan yang Mutunya Sesuai dengan Tanggung Jawabnya. Unsur mutu karyawan PT. Fitria Sarbini Mitra Mandiri Kota Banjarbaru selama ini menjadi perhatian utama, karyawan di haruskan bersikap jujur dan disiplin, jika tidak perusahaan akan memberikan sanksi yang tegas sebagai efek jera dari perbuatannya.

2. Sistem pengendalian intern persediaan bahan baku pada PT. Fitria Sarbini Mitra Mandiri Kota Banjarbaru Kota Banjarbaru yang seharusnya.

a. Struktur Organisasi yang Memisahkan Tanggung Jawab Fungsional secara Tegas. PT. Fitria Sarbini Mitra Mandiri Kota Banjarbaru harus membuat jabatan akuntansi karena pada bagian ini tidak bisa di gabungkan dengan keuangan, Dengan pemisahan fungsi akuntansi dari fungsi-fungsi operasi dan fungsi penyimpanan, catatan akuntansi yang diselenggarakan dapat mencerminkan transaksi sesungguhnya oleh perusahaan.

b. Sistem Wewenang dan Prosedur Pencatatan yang Memberikan Perlindungan yang cukup terhadap Kekayaan, Utang dan Biaya. PT. Fitria Sarbini Mitra Mandiri Kota Banjarbaru Harus dibuat sistem yang mengatur pembagian wewenang untuk otorisasi atas terlaksananya setiap transaksi seperti berkas transaksi yang terlebih dahulu harus dilakukan validasi, hal ini bisa dilakukan dengan cara membuat tim validasi serta audit kedepannya, karena selama ini perusahaan belum memilikinya.

c. Praktik yang Sehat dalam Melaksanakan Tugas dan Fungsi Setiap Unit Organisasi. Caracara yang ditempuh perusahaan dalam menciptakan praktik yang sehat adalah;

a. Penggunaan formulir bernomor urut tercetak yang pemakaianya harus dipertanggung jawabkan oleh yang berwenang.

b. Pengawasan lebih efisien bisa memasang kamera pengawas CCTV pada gudang persediaan PT. Fitria Sarbini Mitra Mandiri Kota Banjarbaru.

c. Setiap transaksi tidak boleh dilaksanakan dari awal sampai akhir oleh satu orang atau satu organisasi.

d. Perputaran jabatan, Jabatan pada PT. Fitria Sarbini Mitra Mandiri Kota Banjarbaru hendaknya dilakukan perputaran secara berkala, serta bisa merekrut orang luar perusahaan yang sudah berpengalaman untuk duduk di jabatan perusahaan.

e. Setiap tahunnya karyawan diwajibkan mengambil cuti agar kejenuhan di perusahaan bisa di hindari.

f. Tim Audit Secara periodik diadakan pencocokan fisik kekayaan dengan catatannya.

d. Karyawan yang jujur harus di perhatikan secara serius oleh perusahaan dan jika tidak jujur harus diberikan tindakan tegas hingga pemecatan secara tidak hormat

\section{DAFTAR PUSTAKA}

Alexandri, Mohm Benny .2014. Manajemen Keuangan Bisnis, Alfabeta, Bandung. 
Amanda, K. 2015. Persepsi Akuntan dan Mahasiswa Akuntansi Terhadap Etika. Profesi Dipandang dari Segi Gender dan Level Hierarki. http:/lejournal.ugb.ac.id diakses tanggal 25 Februari 2018).

Arman Hakim dan Yudha Prasetiyawan, 2014. Perencanan \& Pengendendalian. Produksi. Graha Ilmu. Yogyakarta.

Baridwan, Zaki .2014. Intermediate Accounting. Edisi Ketujuh. Badan Penerbit Fakultas Ekonomi Universitas Gajah Mada. Yogyakarta.

Diana, Anastasia dan Setiawati Lilis .2013. Sistem Informasi Akuntansi,. Perancangan,Proses dan Penerapan. Edisi I. Andi. Yogyakarta.

Dwi Suprajitno. 2014. Analisis Sistem Pengendalian Intern Terhadap Persediaan Bahan Baku Pada PT Surya Indah Kebumen.http://jurnal.umrah.ac.id. Diakses 01 Mei 2018.

Gitosudarmo, Indriyo, 2014. Manajemen Pemasaran, edisi pertama, cetakan keempat, Penerbit : BPFE - Yogyakarta.

Hansen dan Mowen .2014. Akuntansi Manajerial Buku 1 Edisi 8, Salemba Empat, Jakarta, Horngren .2014. Akuntansi: Edisi ke enam: PT Indeks Kelompok Gramedia. Jakarta.

Ikatan Akuntansi Indonesia .2014. PSAK No. 14. Gramedia. Jakarta.

Ismiatun. 2014. Analisis Pengendalian Intern Persediaan Bahan Baku Pada PT. Pulau Bintan Djaya Di Bintan. http://jurnal.umrah.ac.id. Diakses 01 Mei 2018.

Jones .2013. Understanding and Managing Organizational. Behavior. Prentice Hal. New Jersey.

Kasmir, 2014. Pengantar Manajemen Keuangan. Kencana. Jakarta.

Krismiaji, 2015. Sistem Informasi Akuntansi. UPP. AMP YKPN. Yogyakarta.

Martani, Dwi .2014. Akuntansi Keuangan Menengah Berbasis PSAK, Salema Empat. Jakarta.

Mulyadi .2014. Sistem Akuntansi, Edisi ke-3, Cetakan ke-5. Penerbit Salemba. Empat, Jakarta.

Nasution \& Prasetyawan, 2014. Perencanan \& Pengendendalian. Produksi. Graha Ilmu .Yogyakarta.

Natasya Manakey. 2014. Analisis Sistem Pengendalian Intern Pada Persediaan Bahan Baku Perumahan PT. Mitra Cahaya Abadi Kota Bekasi. http://repository.uksw.edu. Diakses 20 Juli 2018.

Prawirosentono .2014. Filosofi Baru Tentang Mutu Terpadu. Edisi 2. Jakarta: Bumi Aksara. Jakarta.

Ristono .2014. Manajemen persediaan edisi 1. Graha Ilmu. Yogyakarta.

Riyanto, Bambang .2014. Dasar-Dasar Pembelanjaan Perusahaan, ed. 4, BPFE-. Yogyakarta. Romney dan Steinbart .2015. Accounting Information. System, Ninth Edition, Prentice Hall.

Rudianto .2013. Pengantar Akuntansi Konsep \& Teknik Penyusunan. Laporan Keuangan, Penerbit : Erlangga, Jakarta

Sartono, Agus .2014. Manajemen Keuangan Teori dan Aplikasi. BPFE. Yogyakarta.

Siregar, dkk .2013. Akuntansi Biaya. Salemba Empat. Jakarta.

Soemarso .2014. Akuntansi : Suatu Pengantar, Cetakan Keempat, Salemba Empat. Jakarta.

Umar, Husein .2013. Metodologi Penelitian Untuk Skripsi dan Tesis Bisnis, PT. Gramedia Pustaka. Jakarta.

Warren .2014. Pengantar. Akuntansi, Edisi 21. Salemba Empat. Jakarta 